\title{
Analysis of the Potential of Renewable Energy in South Sulawesi as Power Electrical Needs
}

\author{
Mochammad Apriyadi Hadi Sirad ${ }^{* 1}$ \\ ${ }^{1}$ Department of Electrical Engineering, Faculty of Engineering and Informatics, University of Patria Artha Makassar \\ J1. Tun Abdul Razak (New Hertasning), Makassar - Gowa, South Sulawesi 92113 \\ *Corresponding author, e-mail: apriyadi.sirat@patria-artha.ac.id
}

\begin{abstract}
The use of electric energy in Indonesia continues to experience the increase, especially in South Sulawesi province. Electric power demand will grow by achieving an average of $6.5 \%$ per year until the year 2022. In this case, the researchers refer to Law number 30 of 2007 concerning energy. Renewable energy in South Sulawesi very potential, so that needs to be held for research potential. This study was carried out in several districts with priority the potential of renewable energy sources is micro-hydro energy, solar energy. Research results show that the potential of solar energy has the most significant potential; namely, the sun shines of $337 \mathrm{MWe}$, with the highest temperature of $95.5^{\circ} \mathrm{C}$ and $\mathrm{pH}$ from 8 to 9. The energy source is located in the Selayar, potentially to develop a solar power plant where the average energy of the solar electricity produced amounted to 2,450 units.
\end{abstract}

Keywords: Renewable Energy, Biomass, Micro Hydro, Wind Power, Solar

\section{Introduction}

The use of electric energy in Indonesia continue to mengalamai the increase, especially in South Sulawesi. These conditions will cause problems if in the provision of electrical energy to the fore is smaller than the required capacity. Electric energy demand will grow by achieving average $6.5 \%$ per year until the year 2022, the condition can be seen from the data consumption of electrical energy per year has increased in line with the national economic growth.

The policy taken (State Electricity Firm) PLN who have a responsibility in terms of providing electrical energy is increasingly indicating that the electrical energy supplied by PLN has only advantages about $3 \mathrm{GW}$. If PLN were not immediately add or build new plants then it will affect the Ministry of electric power to consumers, this may affect economic growth given the electric energy is a necessity in carrying out industrial activity fital large, medium or small industry, and most household appliances.
Many steps or method that is carried out to anticipate these problems by various circles, among other government agencies, the private sector and researchers. The effort is finding the primary energy generation from alternative materials and materials which will not be depleted.

In this case the researchers refer to the law 30 of 2007 about "energy", which discusses the provision of new and renewable energy mandatory enhanced Government and give the ease of to anyone to develop renewable energies Territories respectively. So take the research that discusses the "analysis of the potential of renewable energy in South Sulawesi As electricity needs." The purpose of this research is to obtain data about the potential of renewable energy sources as a source of electrical energy. The purpose of this research is carried out:

a. Inventory data that has the potential of renewable energy in South Sulawesi.

b. Analyzing the sources of energy as an alternative source of renewable energy. 


\section{Review of the Literature}

\section{II.1. Renewable Energy}

The concept of renewable energy is best known in the 1970s as an attempt to compensate for the energy development of nuclear and fossil-fueled. The most common definition is a source of energy that can be quickly recovered naturally, and the process is ongoing. By this definition, then the fossil and nuclear fuels are not included in it. Renewable energy is a natural source of energy that can be directly exploited with impunity and is a resource of non renewable fossil and if managed properly then its resources will not be depleted. Based on its own properties, there is a wide range of energy sources that we encounter in the wild like this the primary source of energy is the energy source that there is direct in nature, this type of renewable energy include Biomass, micro hydro, The Earth's heat, solar power, Wave Power, wind power, and nuclear. A secondary source of energy is the energy that is produced from primary energy more, such as gas and electricity. In addition to its natural properties, based on several sources of energy are also categorized based on availability. Based on availability, energy divided into renewable energy and energy is not renewable.

\section{II.2. The Energy Potential of Biomass-fired Power Bioethanol}

Bioethanol is ethanol made from biomass containing cellulose or starch components, such as cassava and sugar cane molasses. Along with depletion of energy reserves of fuel, bioethanol is expected to be utilized as fuel pensubstitusi fuel for motor gasoline. $\left(\mathrm{C}_{2} \mathrm{H}_{5} \mathrm{OH}\right)$ is a biochemical process of fermentation liquid sugar from the carbohydrate source using the help of micro organisms. Biotermal processing in General, the production of bioethanol this includes 3 (three) set of processes that are:

\section{a. Preparation of Raw Materials}

Raw materials for the production of bioethanol obtained from various plants, either directly produce simple sugars such as sugarcane, sweet corn or produce such as corn starch, cassava and wheat grain sorghum along with other materials.

\section{b. Fermentation}

At this stage, the flour has come to the point has turned into simple sugars (glucose and fructose part) where the next process involves the addition of an enzyme that is placed on the yeast in order to work at optimum temperature. This fermentation process will produce ethanol and $\mathrm{CO}_{2}$.

c. Purification/Distillation

The distillation is done to separate ethanol from beer (most is water and ethanol). The boiling point of pure ethanol is $78{ }^{\circ} \mathrm{C}$ whereas the water is $100{ }^{\circ} \mathrm{C}$ (Standard Conditions). By heating a solution of temperature ranges $(78-100){ }^{\circ} \mathrm{C}$ will result in most of the ethanol evaporates, and through the unit condensation of ethanol will be produced with a concentration of $95 \%$ volume.

\section{II.3. Micro Hydro Power Potential}

Understanding the potential is a quantity the capacity of power plants that may be developed in a particular location plan. There are two main variables which formed the basis of the occurrence process of electric energy generation. Two variables are discharge water and high water fall (head).

Discharge of water is the amount/volume of water per unit of time that will rotate a turbine engine plant. Head is the difference in elevation of the water surface in place of water to the pipe rapidly (penstock) and on the discharge of water from generating machinery (tail race). Calculation of water potential

- Measurement of discharge

Water discharge can be calculated using the formula: $\mathrm{Q}=\mathrm{AV}$, where $\mathrm{Q}$ is the water discharge (in $\mathrm{m} 3 / \mathrm{sec}$ ), $\mathrm{A}$ is the cross-sectional area of flow (in $\mathrm{m} 2$ ) and $\mathrm{V}$ is the velocity of the water flow (in $\mathrm{m} / \mathrm{s}$ ).

- Calculation of head

Calculation of the height of the water fall (head) on the channel can be determined with the following formula:

$$
\begin{aligned}
& \mathrm{H}=\frac{Q^{\mathbb{2}}}{2 g(b \cdot C d(H 2-H 1))^{2}} \\
& \mathrm{Hs}=\mathrm{H}_{2}-\mathrm{H}, \mathrm{Cd}=0,6 \text { (coefficient of discharge) } \\
& \text { (Triatmodjo, 1996) }
\end{aligned}
$$

- Calculate the potential power

To calculate the potential power that promoted; the calculation formula is as follows:

$$
P_{t}=\rho . g . Q . H n . ~ \eta o
$$


with:

$\mathrm{P}_{\mathrm{t}}=$ power is able to $(\mathrm{W})$,

$\rho=$ a mass meeting of the waters $\left(\mathrm{kg} / \mathrm{m}^{3}\right)$,

$\mathrm{g}=$ grafitasi $\left(\mathrm{m}^{2} /\right.$ detik $)$,

$\mathrm{Q}=$ volumetric flow $\left(\mathrm{m}^{3} /\right.$ detik $)$,

$\mathrm{Hn}=$ high fall clean $(\mathrm{m})$,

$\eta о=$ efisiensi overall, $50-70 \%$

(Source: JICA, 2003)

\section{II.4. Solar Power Energy}

Renewable energy solar energy is the energy that converts solar energy into electrical current to be in line with the use of thin silicon. Solar power/solar is a source of large amounts of energy, are continuous, and very attractive, because of the nature of kollotif, cannot be depleted and credible as well as free.

In effect the solar cell photovoltaics semiconductor diodes are a work in progress is not balanced and based on the photovoltaic effect. In the process it's solar cell produces 0.5-1 volt voltage dependent intesitas light and semiconductor substances are used. The intensity of the energy contained in sunlight to Earth to the surface the magnitude of about 1000 watts of power, but due to the conversion of radiant energy into electrical energy based on new photovoltaic effect reached $25 \%$, then the maximum electricity production is generated a new solar cell reaches 250 Watts per $\mathrm{m} 2$. The country belongs to the tropical region of Indonesia has the potential of solar energy. This is apparent from daily radiation i.e. amounting to 4.5 $\mathrm{kWh} / \mathrm{m} 2 /$ day, this gives indications that the prospect of the use of photovoltaics in the future is quite bright.

The working principle of the solar power plant of a cylindrical crystal of Silicon (Si) is obtained by means of heat $\mathrm{Si}$ it with pressure adjusted so that it turns into The carriage. When it was cut as thick cylindrical crystal of $0.3 \mathrm{~mm}$, will be making silicon cells are thin or also called photovoltaic solar cells. Silicon cells were mounted with the position of the parallel/series in a panel made of aluminum or stainless steel and protected by glass or plastic.

Then in each cell were given connection electrical connections. When cells are exposed to the Sun it is in connection to that electrical current will flow. The magnitude of the currents of electricity that depends on the amount of light energy that reaches the silicon cell surface area and it was. Electromagnetic energy can also be converted directly into electrical energy in the selfotovoltaic or often called Sun. The advantages of solar photovoltaic power station with, among other things:

1) Energy used is the energy that is available for free.

2) Treatment is easy and simple.

3) There is no equipment to move, so it doesn't need replacement parts and Setup on lubrication

4) The equipment works without sound and does not negatively impact the environment.

5) Can work automatically.

\section{II.5. Wind Energy}

Wind is moving air caused by the rotation of the Earth and also due to the difference in air pressure around it. The wind moves from where air pressure is high to low air pressure. When heated, the air expands. The air has become lighter so as to expand the ride. When this happens, the air pressure dropped because the air is reduced. The surrounding cold air flows into the low-pressure place. Air shrink become heavier and fall to the ground. Above ground air into penas again and climb back. Single windmill Propeller type (propeller), in this type windmill placed aligned towards the direction of the wind gusts. The type of Shaker eggs (eggbeater) in this type windmill placed perpendicular to the direction of the wind gusts. Power supplied by wind power is derived from the kinetic energy equation as follows:

Because

$$
P_{\text {wind }}=\frac{E_{k} \text { wind }}{t}=\frac{1}{2} m^{0} v^{2} \ldots
$$

$$
m^{0}=m / t=\rho A V \square \text { and } A=\pi D^{2} / 4
$$

then

$$
m^{0}=\frac{\rho \pi D^{2} V}{4}
$$

by entering the equation (2) in equation (1) is obtained:

$$
P_{\text {Wind }}=\frac{1}{2} \frac{\rho \pi D^{2} V}{4} V^{2}=\frac{\rho \pi D^{2} V^{3}}{8} .
$$

where

$$
\begin{gathered}
\mathrm{P}_{\text {Wind }}=\text { wind power }(\mathrm{watt}) \\
\mathrm{m}^{0}=\text { wind flow period }(\mathrm{kg} / \mathrm{s})
\end{gathered}
$$

$\rho \quad=$ density of air $=1,29 \mathrm{~kg} / \mathrm{m} 3$

$\mathrm{D} \quad=$ the diameter of the Wind mill (m) 
$\mathrm{V} \quad=$ wind speed $(\mathrm{m} / \mathrm{s})$

While the power of the rotor is given according to the following equation:

$$
P_{\text {rotor }}=0.5 C_{p} \rho A V^{3} 3
$$

where:

$\mathrm{P}_{\text {rotor }}=$ Mechanical power wind turbine (Watt)

$\mathrm{Cp}=$ Rotor power transfer coefficient (Constants Betz)

If the data transmission efficiency is mechanical and efficiency is generator Note electrical output power magnitude mak generator turbine with coupling are:

$$
P_{\text {out }}=0.5 \eta_{t} \eta_{g} C_{p} \rho A V^{3}
$$

\section{Methodology}

This research is deskristif research that aims to find out the potential of renewable energy in South Sulawesi. In this research field survey tool is required to know the potential of renewable energy that exists in the area of research. Methods of data collection the survey is done through the instansional (secondary data) and field survey (primary data).

The survey data are secondary data collection or map number, the potential energy of the water and the sun shines. Primary data is the survey data collection activities based on checking in the field and measurements.

\section{Results and Discussion}

\section{IV.1. The Energy Potential of Hydro Electric Power}

Hydroelectric water power currently available in South Sulawesi that is mounted on the grid can be seen in the following table:

TABLE I

Hydroelectric Power Plant In SOUTH Sulawesi

\begin{tabular}{ccr}
\hline No. & Name of the location & Total capacity \\
\hline 1 & PLTA Bakaru & $126 \mathrm{MW}$ \\
2 & PLTA Balambano & $140 \mathrm{MW}$ \\
3 & PLTA Larona & $135 \mathrm{MW}$ \\
4 & PLTA Karabbe & $90 \mathrm{MW}$ \\
5 & PLTA Bilibili & $20 \mathrm{MW}$ \\
\hline & Total & $511 \mathrm{MW}$ \\
\hline
\end{tabular}

Source: PT. PLN Persero Sulselbar 2015
The potential of renewable energy Hydropower in South Sulawesi can be seen on the following map:
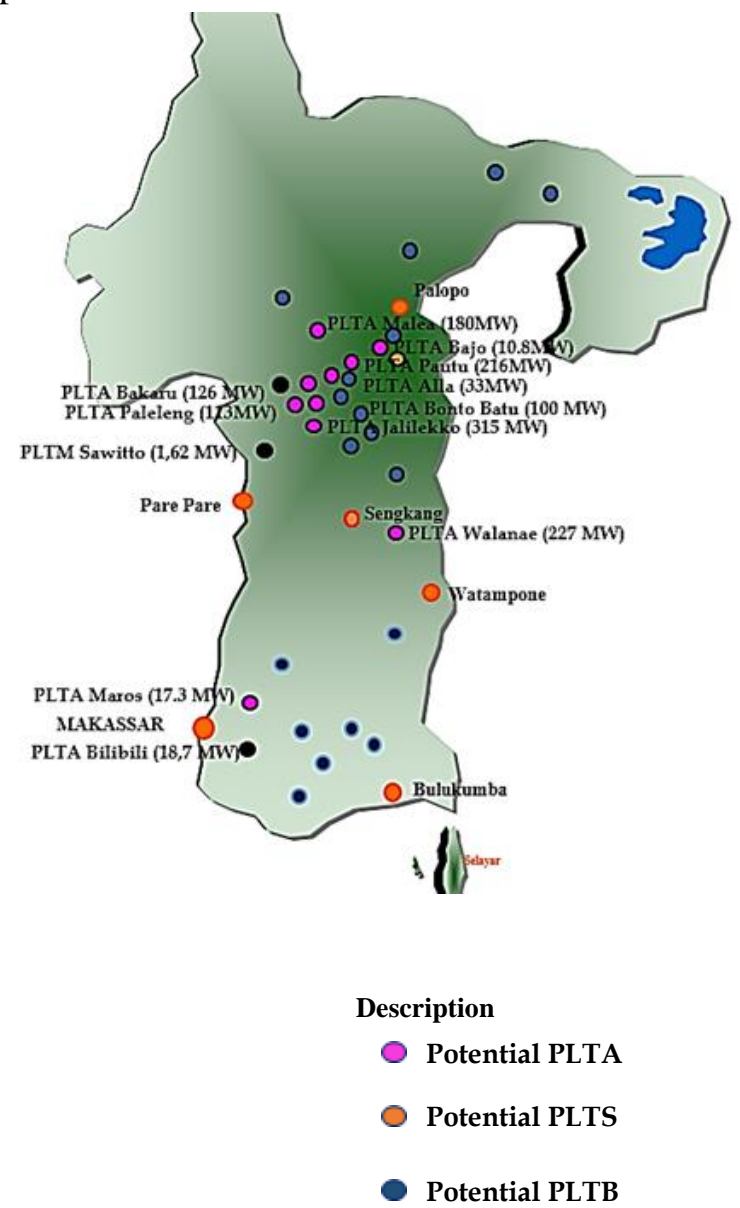

Fig. 1. Map of the Province of South Sulawesi

TABLE 2

Water POWER Plant In INSTALLED (ON GRID)

\begin{tabular}{lrc}
\hline Regency & $\begin{array}{c}\text { Installed } \\
\text { power (MW) }\end{array}$ & $\begin{array}{c}\text { Number of locations } \\
\text { hydropower }\end{array}$ \\
\hline Pinrang & 443,0 & 3 \\
Tana Toraja & 360,0 & 2 \\
Enrekang & 656,0 & 5 \\
Maros & 17,3 & 1 \\
Gowa & 20,0 & 1 \\
Luwu & 240,8 & 2 \\
Sidrap & 494,1 & 1 \\
Soppeng & 227,4 & 2 \\
Jeneponto & 13,2 & 1 \\
East Luwu & 475,0 & 1 \\
\hline \multicolumn{1}{c}{ Total } & $2.946,8$ & 19 \\
\hline
\end{tabular}

In this study data obtained for potential renewable energy micro-hydro power plant in South Sulawesi that is amounting to $5.094,3 \mathrm{MW}$ which spread on the Regency in South Sulawesi, among others, can be seen in Table 3: 
TABLE 3

Potential Renewable ENERgy Micro-Hydro Power Plant

\begin{tabular}{lrr}
\hline \multicolumn{1}{c}{ Regency } & \multicolumn{1}{c}{ Total } & The capacity \\
\hline Enrekang & 13 Unit & $696 \mathrm{Kw}$ \\
Bantaeng & 1 Unit & $20 \mathrm{Kw}$ \\
Tana Toraja & 106 Unit & $1.873 \mathrm{Kw}$ \\
L u w u & 26 Unit & $786,5 \mathrm{Kw}$ \\
Luwu Utara & 18 Unit & $320 \mathrm{Kw}$ \\
Pinrang & 4 Unit & $79 \mathrm{Kw}$ \\
Sidrap & 4 Unit & $88 \mathrm{Kw}$ \\
Selayar & 1 Unit & $10 \mathrm{Kw}$ \\
Gowa & 3 Unit & $211 \mathrm{Kw}$ \\
Palopo & 1 Unit & $400 \mathrm{Kw}$ \\
Sinjai & 6 Unit & $110 \mathrm{Kw}$ \\
Barru & 9 Unit & $83 \mathrm{Kw}$ \\
Bulukumba & 1 Unit & $30 \mathrm{Kw}$ \\
Toraja Utara & 27 Unit & $387,8 \mathrm{Kw}$ \\
\hline \multicolumn{1}{c}{ Total } & 219 Unit & $5.094,3 \mathrm{Kw}$ \\
\hline
\end{tabular}

\section{IV.2. The Potential of Solar Energy}

Of research data, the potential of solar energy that they would for the utilization of energy in South Sulawesi which are already used as solar power plant.

TABLE 4

The Potential of Solar Energy in South Sulawesi

\begin{tabular}{|c|c|c|c|}
\hline Location & Potential & (Mwe) & Description \\
\hline Selayar & Speculative & 25 & $\begin{array}{c}\text { Temp. } 95.5^{\circ} \mathrm{C}, \\
\text { pH }=8-9\end{array}$ \\
\hline $\begin{array}{c}\text { Pararra North } \\
\text { Luwu }\end{array}$ & Indicated & 20 & $\begin{array}{l}\text { Temp. } 56^{\circ} \mathrm{C}, \\
\text { Debit }=11 / \mathrm{dt}\end{array}$ \\
\hline Panggak, Sinjai & Speculative & 25 & $\begin{array}{c}\text { Temp. } 65-66 \\
{ }^{\circ} \mathrm{C}\end{array}$ \\
\hline $\begin{array}{l}\text { Massepe, } \\
\text { Sidrap }\end{array}$ & Speculative & 25 & $\begin{array}{c}\text { Temp. } 65-70 \\
{ }^{\circ} \mathrm{C}, \mathrm{pH}=7\end{array}$ \\
\hline Sulili, Pinrang & Speculative & 25 & $\begin{array}{c}\text { Temp. } 56{ }^{\circ} \mathrm{C} \\
\text { pH }=7,5\end{array}$ \\
\hline $\begin{array}{c}\text { Ds. Tompo, } \\
\text { Barru }\end{array}$ & Speculative & 25 & $\begin{array}{c}\text { Temp. } 75^{\circ} \mathrm{C}, \\
\mathrm{pH}=7\end{array}$ \\
\hline Bituang, Tator & Indicated & 17 & $\begin{array}{c}\text { Temp. } 65-66 \\
{ }^{\circ} \mathrm{C}\end{array}$ \\
\hline Sangala, Tator & Indicated & 25 & $\begin{array}{l}\text { Temp. } 56^{\circ} \mathrm{C}, \\
\text { Debit }=11 / \mathrm{dt}\end{array}$ \\
\hline Sengkang & Indicated & 25 & $\begin{array}{c}\text { Temp. } 75^{\circ} \mathrm{C} \\
\mathrm{pH}=7\end{array}$ \\
\hline Malawa & Indicated & 25 & $\begin{array}{c}\text { Temp. } 56{ }^{\circ} \mathrm{C} \\
\mathrm{pH}=7,5\end{array}$ \\
\hline Todong, Bone & Indicated & 25 & $\begin{array}{c}\text { Temp. } 95.5^{\circ} \mathrm{C}, \\
\mathrm{Ph}=8-9\end{array}$ \\
\hline Barru & Indicated & 25 & $\begin{array}{c}\text { Temp. } 75^{\circ} \mathrm{C} \\
\mathrm{pH}=7\end{array}$ \\
\hline Watampone & Indicated & 25 & $\begin{array}{c}\text { Temp. } 56^{\circ} \mathrm{C} \\
\mathrm{pH}=7,5\end{array}$ \\
\hline Sidrap & Indicated & 25 & $\begin{array}{c}\text { Temp. } 56^{\circ} \mathrm{C} \\
\mathrm{pH}=7,5\end{array}$ \\
\hline \multicolumn{2}{|c|}{ Total } & 337 & \\
\hline
\end{tabular}

In this study data obtained for potential renewable energy solar power plant in South Sulawesi, i.e. of 14,874 Units which are scattered on the Regency in South Sulawesi, among others, can be seen in Table 5 .

TABLE 5

THE POTENTIAL OF SOlar ENERGY

\begin{tabular}{clc}
\hline No. & Regency & The number of units \\
\hline 1 & Bantaeng & 352 \\
2 & Enrekang & 510 \\
3 & Wajo & 761 \\
4 & Soppeng & 450 \\
5 & Takalar & 553 \\
6 & Pinrang & 432 \\
7 & Tana Toraja & 803 \\
8 & Jeneponto & 615 \\
9 & Bulukumba & 543 \\
10 & Gowa & 765 \\
11 & Lutim & 338 \\
12 & Palopo & 320 \\
13 & Lutra & 480 \\
14 & Barru & 345 \\
15 & Pangkep & 703 \\
16 & Maros & 635 \\
17 & Luwu & 1.435 \\
18 & Bone & 936 \\
19 & Selayar & 2.450 \\
20 & Sidrap & 285 \\
21 & Sinjai & 553 \\
\hline & Total & 14.874 \\
\hline
\end{tabular}

\section{Conclusion}

It is strongly encouraged that the authors may use SI (International System of Units) units only.

1) The energy potential of Hydroelectric Power can be a reliable source of energy and enter to the intermediate scale range as much as 219 units with 5,094.3 power Kw.

2)Development of microhydro power plant should be considered so as not to disrupt the unity of living things around it.

3) Based on the results of the calculation of the sun shines of 337 mwe, with the highest temperature i.e. $95.5^{\circ} \mathrm{c}, \mathrm{Ph}=8-9$ that is located in the Selayar potentially to develop solar power plant where the average energy of the solar electricity produced amounted to 2,450 units.

\section{References}

[1] Adelhard Beni Rehiara, 2008. Analisis Potensi Angin Sebagai Penggerak Pembangkit Listrik Tenaga Angin Pada Daerah Pesisir Pantai Utara 
Kabupaten Manokwari, Manuscript. Jurnal Widya Teknik,.

[2] Hambali Erliza, 2007. Teknologi Bioenergi. Cet.1 Agromedia Pustaka, Jakarta,

[3] Patel, Mukind R. 1942. Wind and Solar Power Systems, Library of Congress Card Number 9847934, USA,.

[4] Yushardi, November, 2002. Makalah Pengantar Falsafah Sains (PPS702) Program Pasca Sarjana / S3, Institut Pertanian Bogor,.

[5] Juhari AB, dkk, 2009, Optimization of PV-WindHydro-Diesel Hibrid Sistem by Minimizing Excess Capacity, European Journal of Scientific Research.

[6] Wang, Cheisang, 2008, Power Management of a stand-alone Wind/Photovoltaic/Fuel Cell Energi System, IEEE Transaction on Energi Conversion, Vol 23 No.3.

[7] Agus Sugiyono, 2006, Penanggulangan Pemanasan Global Di Sektor Pengguna Energi, JurusanTeknik Fisika, Fakultas Teknik Universitas Gadjah Mada "Pengembangan Energi Terbarukan Studi Kasus Di Yogyakarta" Yogyakarta.

\section{Authors' information}

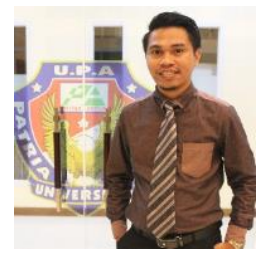

Mochammad Apriyadi Hadi Sirad received a Bachelor of Engineering Degree From the Department of Electrical Engineering from the Muslim University of Indonesia Makassar in 2006, While the Master of Engineering Degree from the Department of Electrical Power Engineering, Hasanuddin University, Makassar, in 2014. Mochammad Apriyadi Hadi Sirad, S.T.,M.T. is the Chairman of the study Program Electrical Engineering, Faculty of Engineering And Informatics, Patria Artha University Makassar Indonesia. Researching about being in Power System Analysis, Optimization, Distributed Energy Resources, and Renewable Energy. 